\title{
The Races of Europe: Construction of National Identities in the Social Sciences, 1839-1939
}

\author{
Review Number: 2173 \\ Publish date: Thursday, 21 September, 2017 \\ Author: Richard McMahon \\ ISBN: 9780230363199 \\ Date of Publication: 2016 \\ Price: $£ 60.00$ \\ Pages: 484pp. \\ Publisher: Palgrave \\ Publisher url: https://www.palgrave.com/in/book/9780230363199 \\ Place of Publication: London \\ Reviewer: Ian Stewart
}

The emergence of racial classification in conjunction with the Enlightenment Science of Man in the 18th century is a well-known chapter in the history of European ideas. Far less understood are the ways in which this scientific project carried into the 19th and 20th centuries, the investigation of which is Richard McMahon's purpose in The Races of Europe. He seeks to illustrate not only how the race sciences operated across Europe from c.1839-c.1939 (though the book is sensitive to the long prehistory of modern racialism), but how 'national identities' and nationalist discourses were constructed within them. Obviously the aim is an ambitious one, but McMahon succeeds in providing a useful survey of European race science, punctuated with novel findings from his methodology and case studies. Crucially, the book treats race science on its own terms, historicising the contributions of its practitioners rather than reading them through any particular theoretical lens - postcolonial or otherwise - as has been popular in recent decades.

The book is split into two halves, the first of which provides a kaleidoscopic account of the European network of race classifiers, their interactions and techniques, and the political implications of their work. Case studies of Ireland, Poland, and Romania comprise the second half of the book, and serve to reinforce the interpretation of the overall European picture painted in part one. McMahon presents his work as a 'transnational history of national identity' (p. 1), describing how race scientists aimed to reveal the "'true" identities of European nations' through biological racial classification. Despite this framing, the book is not easily classifiable, repeatedly crossing scholarly boundaries, both disciplinary and geographical; this approach should be welcomed as it mirrors the multi-disciplinarity of McMahon's international subjects, as 19th-century racial classification was spread across various academic disciplines (as they exist today) and most of the European continent.

In part one, McMahon is largely concerned with establishing a geography of racial classification in Europe, where the three 'core' nations of Britain, France, and Germany spurred most racial research. However, as the 19th century wore on, classificatory race science expanded outwards from this core, though the three nations remained dominant. Here the author should be commended for going beyond the normal comparative framework of Britain, France, and Germany, instead aiming to provide a true European picture - supported by case studies of the refreshingly novel choices of Ireland, Romania, and Poland. Most intriguingly, as 
outlined in chapter two, McMahon has constructed his geography through a quantitative database of 126 source texts, from what he identifies as the 'elite' of racial classifiers. Aware of the subjective imperfection of his method and of quantitative limitations more generally, McMahon does not rely on the database overmuch. This may be because it seems to prop up findings already more or less known, or at least suspected. For example, few familiar with the field will be surprised that Paris is confirmed by the data to have been the 19th-century racial classification capital (p. 50). More interesting is McMahon's use of transnational comparison to contribute to the Sonderweg debate, suggesting that German anthropology was more monogenist and egalitarian than the contemporary (Robert Knox-inspired) London Anthropological Society or the Parisian anthropologicals (p. 57). The geographical picture - made clearer by the useful inclusion of 24 maps in the appendix - established early on helps to frame McMahon's findings through the rest of the book.

A timeline for race science is also established in part one, with an obvious increase in the complexity of racial classification as well as its adaptability through different intellectual paradigms. The most significant change within race science was the shift in the middle of the 19th century from the long-established ethnolinguistic understandings of race to more hard and fast physiological distinctions between nations. Here the established geography repeatedly provides the context for a clash between the waning currents of Enlightened universalism and local national imperatives. Although the community of racial scientists remained internationally focused throughout the 19th century, by the fin de siècle any notion of a common project had collapsed as nationalism overshadowed scientific objectivity. However, for superior races there had to be inferior ones, so to some extent racial classification was always transnational and comparative. In the 20th century European geographical classifications came to replace long-established racial delineations. For example, 'Nordicism' encompassed the Germanic-speaking peoples as the Indo-European, or Aryan, idea was set aside in these countries (pp. 171-2).

McMahon explores the relationship between race science and politics in the fourth chapter of the work, foregrounded as a 'central theme' in his introduction (pp. 1-2). An obvious factor here is that scientists more or less relied on politicians - via the state - to fund their research, which had implications for the racial narratives they created and against which nations they directed them. But most scientists were also nationalists to varying degrees and so a tension between local imperatives and international scholarly objectivity was also evident across Europe. As the 19th century wore on, universalism mattered less and less as nationalist dimensions took over. The most striking example included here came when the French anthropologist Paul Broca found that his data forced him into the inconvenient conclusion that the majority of Frenchmen were brachycephalic rather than dolichocephalic (round-headed as opposed to long, narrowheaded), the opposite of common assumptions. What could Broca do? Fudge the data? Or reorder craniological hierarchies? Remarkably, he chose the latter, turning the established sequence of craniological prestige on its (broad) head, so that brachycephalic became perceived as the most prestigious skull shape in French racial science. This had wide ramifications as the Slavs were also thought brachycephalic. The French therefore suddenly found they had Celto-Slav relatives, at the same time as the great power politics of France and Russia aligned.

In part two, titled 'Peripheral case studies', McMahon seeks to bolster his geography of the three 'core' classifying nations in northwest Europe, by showing how 'peripheral' race science largely mirrored the established categories and narratives of European race science, forcing their way into European consideration rather than establishing their own racial narratives and traditions. I will here focus on Ireland as it is the case with which I am most familiar, but the case studies of Poland and Romania show similar themes of tension between a reliance on racial ideologies constructed in the three core nations and a nationalist desire to cast their own race as certainly equal and perhaps superior to those in the core nations.

The Irish case study is notable for several reasons, not the least of which - as McMahon points out - is that there is no study of 19th-century Irish race science. A survey of the (few) Irish race scientists - including William Wilde (Oscar's father) - shows that they essentially transposed a British anthropological framework on top of their origins traditions. But painting a picture as lucid as McMahon's is no easy task, not only due 
to a dearth of 19th-century anthropological source material relative to other nations, but because Irish origin stories are a jumbled mixture of native mythology, sacred history, and ideas of descent from the Celts, Scythians, and Phoenicians that were popular across Europe. Mythology continued to shape ideas of the early Irish - particularly the Fír Bolg and Túatha Dé Danann, the 'gods' of Irish mythology - through the 19th century. Race scientists were forced to confront these popular myths, and in a sort of national euhemerism tried to discern who these populations were and whence they came. This is emphatically not a story of early Celtic inhabitants being conquered by Anglo-Norman invaders in the 12th century that a reader unfamiliar with Irish origins stories might suppose. Nor was there a straightforward equation of all native Catholic Irish with the ancient Celts, as racial classifiers sought to determine which parts of the population could be physically linked with the numerous invaders. Compounding the fractured picture of Irish race science were Ireland's close intellectual links to Britain and Germany, all of which McMahon suggests led to Ireland's racial focus on a vague, spiritual Gaelicism rather than a traditional superior-race narrative.

The book is meticulously researched and, though he makes no claims to be comprehensive, McMahon has gone some way to giving us a much clearer picture of the landscape of European racial science in the 19th and 20th centuries. However, there are some problems. Because of the large amount of synthesis necessary to constructing a clearer account of race science over the entirety of Europe, McMahon relies quite heavily at times on secondary sources, some of which (1) have been challenged and heavily qualified in recent years. McMahon has also had the considerable challenge of finding a vocabulary able to describe a perpetually shifting discipline, operating in different languages across the entire European continent over two centuries. Unfortunately, a phrase like 'Enlightenment period assumptions of White global racial superiority' (p. 171) might make sense to modern ears, but was emphatically not the idiom of 'the' Enlightenment, where 'race' was largely still linked to ethnic descent. The overarching concern of Enlightenment anthropology - most of whose practitioners were Christian and therefore believed in the unity of humanity - was to explain why certain tribes/nations reached a higher level of civilisation than others; in this context, the idea of original racial difference was tentatively floated by a few heterodox thinkers, but the influence of climate remained the salient consideration into the 19th century. 'Romantic' and 'romanticism' also do a considerable amount of linguistic work, and while every reader will perhaps have some idea of what is meant, it is never quite clear how romantic ideologies changed race science. Finally, given how wide-ranging the book is, a few more dates could perhaps have been given (i.e., the birth and death years of each scientist discussed).

While these shortcomings should be borne in mind, it must be emphasised that the importance of the work as a whole far outweighs any deficiencies. It will sit alongside classics like Leon Poliakov's Le mythe aryen (2) , and add a level of technical sophistication - literally, as McMahon shows the physical construction of racial narratives through data collection and physical measurements - on top of the standard understandings of Celtic, Teutonic, Indo-Germanic, Aryan, Nordic etc. racial narratives. McMahon ranges across the 19thcentury disciplines of racial science - philology, ethnology, anthropology, history, and folklore - but seems most at home in the realm of anthropology and the technical discussions of race science. Happily so, as the debates in the latter half of the century are some of the most confused and abstruse; McMahon's syntheses will therefore aid those familiar with the history of race science as well as newcomers to the field.

The Races of Europe is a unique work that makes a valuable contribution to the histories of ideas and science, while also linking them to the cultural history of national identities. This review can neither do justice to the amount of information corralled nor to the skill involved in weaving widely differing theories into a coherent picture of European race science in a series of intellectually manageable chapters. Scholars interested in the history of race science and racialism more broadly will find it particularly useful, but it will appeal to others across a wide variety of related fields. McMahon ends with an epilogue setting out some of the risks related to the study of genetics and its potential for biological essentialism, warning scientists that how their research is appropriated beyond the academy is largely out of their hands. I think there is also a lesson for the humanities here: as McMahon's examples repeatedly show, national identity construction from biological evidence was highly subjective and historically contingent, though its practitioners claimed 
it proved immemorial racial truths. This should be a powerful reminder to those scholars who, though purporting to illuminate the oppression of subalterns, have cast certain 'identities' and the power dynamics around them as immemorial without realising the ways in which they echo the racialised discourses they aim to combat.

\section{Notes}

1. L. P. Curtis, Anglo-Saxons \& Celts: A Study of Anti-Irish Prejudice in Victorian England (Bridgeport, 1968). Back to (1)

2. Leon Poliakov's Le mythe aryen (Paris, 1971).

Source URL:https://reviews.history.ac.uk/review/2173

\section{Links}

[1] https://reviews.history.ac.uk/item/242355 